\title{
KONTEKST JA VIITAMINE: ARGIVESTLUSED, LEGOD JA NARRATIIVID ${ }^{1}$
}

\author{
Helen Hint, Maria Reile, Renate Pajusalu \\ Tartu Ülikool
}

Kokkuvõte. Käesolev artikkel käsitleb konteksti ja viitamisvahendeid, mis loovad konteksti. Käsitlus põhineb eelkõige kolmel eraldi läbiviidud uurimusel, milles kõigis oli põhitähelepanu algselt suunatud viitamisvahenditele. Vaatleme kontekstualiseerimisvõtteid spontaansetes argivestlustes ja kahes katselises olukorras: katses legoklotsidega, milles üks katsealune ehitab klotsidest maja teise katsealuse juhendamisel, ja pildiseeria põhjal jutustatud narratiivides. Artiklis võrreldakse, mis nendes kolmes kontekstis oli sarnast ja mis erinevat eelkõige vestlustegevuse alguses: tegevuse olemusest märku andmises ja referentide loomises. Kuna üks osa vaadeldavaid narratiive pärineb lastelt, puudutab artikkel mõnevõrra ka erinevate vanuseliste gruppide viitamisstrateegiaid.

Märksõnad:referents, definiitsus, demonstratiivid, pronoomenid,narratiiv, argivestlus, lapsekeel, eesti keel

\section{Kontekst ja viitamine: üldine sissejuhatus}

Kontekst on igasuguse keelekasutuse oluline osa. Kuigi kontekstist räägitakse keeleteaduses palju, ei ole tegelikult olemas ühiselt aktsepteeritavat loendit neist nähtustest, mida kontekstina peaks vaatlema. Raamatu "Rethinking context” eessõnas (Duranti, Goodwin 1992: 2) ütlevad toimetajad, et täpsemat definitsiooni tegelikult vaja ei olegi: termin kontekst inspireerib paljusid keeleuurijad hoolimata oma hägususest. Olulisim näib olevat, et kui räägitakse kontekstist, siis mõeldakse üldiselt seda, et vaadeldav nähtus ei ole mõistetav ilma taustateadmisteta (samas: 3). Siiski loetletakse (samas: 6-7) kolm põhilist valdkonda, mis on konteksti uurimisel relevantsed: tegevuspaik (setting), mis hõlmab suhtlustegevuse ruumilist ja sotsiaalset

1 Uurimust on toetanud ETFi grant 7492 ja sihtfinantseeritav teema SF0180056s08 
võrgustikku, sealhulgas ka deiktilist tausta; osalejate käitumine, mille all mõeldakse žeste, tähelepanu jms; ning keelelised kontekstualiseerimisvihjed.

Kontekstualiseerimisvihjed (contextualisation cues) on defineerinud ja nende rolli suhtluses kirjeldanud John J. Gumperz (1982: 131-152). Kontekstualiseerimisvihje on mis tahes vormielement, mis signaliseerib kontekstuaalset presupositsiooni (samas: 131). Gumperz nimetab oma käsitluses kolme funktsiooni, mis neil vihjetel on: 1) kõneleja saab nende abil märku anda ja kuulaja tõlgendada, mida parajasti tehakse, st milline suhtlustegevus on käimas; 2) need annavad aimu, kuidas lausungis semantilist sisu tuleks mõista ja 3) näitavad, kuidas öeldu suhestub eelneva ja järgnevaga. Kontekstualiseerivad vihjed ei ole diskreetsed märgid, nad võivad olla nõrgemad ja tugevamad, ilmsemad ja varjatumad, st skalaarsed (samas: 132). Hilisemas artiklis loetleb Gumperz (1992: 231) ka valdkonnad, mis on kontekstualiseerimise seisukohalt kõige olulisemad: prosoodia, paralingvistilised vahendid, koodi ja leksikaalsete vahendite valik.

Gumperz ise käsitleb eelkõige neid vihjeid, mis signaliseerivad mingit kõrvalekallet normist, st neid, mille puhul kõnelejad vastastikku tajuvad, et vestluses on midagi ebatavalist. Ta toob näiteid sellest, kuidas üks suhtlejatest ei mõista teise kujundliku keelekasutuse kaudu pakutud suhtlusstiili (samas: 133) või kuidas keeleüksuse rõhutamise kaudu abikaasad omavahel nääklevad (samas: 135). Samas on aga hulganisti vahendeid, mis vihjavad kontekstile ka „normaalselt”, juhatades näiteks sisse mingi suhtlustegevuse tüübi.

Suhtluse kontekst muutub kogu aeg. Et konteksti muutusi käsitleda, võime selle laias laastus jagada kaheks omavahel läbipõimunud dimensiooniks: tekstiväliseks ja tekstisiseseks (vt ka nt Lambrecht 1994: 36-37). Tekstivälises maailmas võivad muutuda füüsilise reaalsuse näitajad, näiteks vahetavad vestlejad asukohta. Samuti muutuvad osalejate rollid vestluses: kõnelejast saab kuulaja, kõrvalseisjast osavõtja jne.

Viitamine ehk referentsiaalne akt on suhtlustegu, mille käigus mingi märgi (keelelise üksuse või žesti) abil osutatakse entiteedile, millest räägitakse. Viitamise kaudu moodustub dis- 
kursuse referent, st käimasoleva suhtluse raamistikku kuuluv mentaalne representatsioon. Uuele referendile viidatakse üldjuhul indefiniitse fraasiga ja vestlusest osavõtjad peavad selle referendi kõigepealt käimasolevas vestluses kasutatavate representatsioonide hulka paigaldama. Kui referent on juba korra paigaldatud, siis viidatakse sellele uuesti definiitse fraasiga. Keeliti on (in)definiitse fraasi vormilised tunnused muidugi erinevad. (vt nt Lyons 1999, Laury 1999, Pajusalu 2002)

Siinses uurimuses on omaks võetud seisukoht, et referendid sünnivad suhtluse või teksti kirjutamise/vastuvõtmise käigus, referentsiaalne akt on loov ja muudab konteksti tulevaste suhtlussündmuste jaoks (vt ka Silverstein 1976: 34). Referendid ei ole meie käsitluses seega mitte püsivad entiteedid füüsilises maailmas, vaid dünaamilised mentaalsed representatsioonid (Lambrecht 1994: 38, Etelämäki 2009: 26). Maailma kirjeldades ehitatakse see ühtlasi ka üles (Hanks 1996: 237).

Viitamine sõltub ka käimasoleva suhtlustegevuse olemusest. Viitavaid keeleüksusi kasutatakse erinevalt sõltuvalt sellest, kas näiteks jutustatakse ammustest sündmustest, juhitakse vestlusringi või parandatakse autot. William F. Hanks (1996: 229) on kirjutanud: „Inimesed, kes jagavad samu kategooriaid, /.../, võivad üksteisest täiesti valesti aru saada, kui nad tõlgendavad erinevalt käimasolevaid suhtlustegevusi”.

Referentidega toimuvatest muutustest on keeleteaduses ehk enim uuritud infostaatuse muutumist infovoolus (vt nt Gundel jt 1993, Gundel jt 2010, Chafe 1994, Lambrecht 1994, Ariel 2001). Korra nimetatud referent ei ole enam uus, iga uue referendi lisandumisega muutub suhtlussündmuse referentide mentaalsete representatsioonide võrgustik, samas vestluses tihti nimetatavast referendist moodustub jutustuse peategelane jne. Kõnelejal on tarvis ka keelelisi vahendeid referentide infostaatuse pideva muutumise väljendamiseks. Keelelisi vahendeid, millega kõneleja väljendab NP tuntust või tundmatust, nimetatakse määratlejateks. Seega sarnanevad määratlejad teatud mõttes grammatilisele artiklile, ent nende kasutus ei ole grammatiliselt reglementeeritud ning nende hulk ei ole suletud (vt nt Abbott 2010). 
Viidata võib iga nimisõnafraas, kuid keeleteadlaste erilise tähelepanu all on olnud pronoomenite, eriti demonstratiivide, referentsiaalsed omadused. Näiteks soome demonstratiivide tämä, se ja tuo viitavaid omadusi on varem seostatud referendi ruumilise asukohaga (Larjavaara 1990), hilisemal ajal on aga pigem oletatud, et ruumilistest tähtsamad on referendi need omadused, mis on seotud vestluse käigu ja kõnelejate suhetega (nt Laury 1997). Vestlusanalüüsi traditsioonis on Marja Etelämäki (2009) soome demonstratiivide kohta väitnud, et nende referentsiaalsed omadused on ühelt poolt interpreteeritavad käimasoleva vestlustoimingu kaudu, teiselt poolt aga on just demonstratiivpronoomenitel kui referentsiaalsetel indeksitel (vt Silverstein 1976) oluline roll vestlustoimingu identifitseerimisel. Eesti keele osas pole sellise vaatenurgaga uurimusi veel kuigi palju tehtud, kuid mõned näited sellest, kuidas pronoomenid konteksti loovad, võib siiski tuua: teie kasutamine vestluspartneri poole pöördudes näitab kogu suhtlusolukorra formaalsust ja distantseeritust; too kasutamine isikuviitelisena signaliseerib kas kõneleja lõunaeestilist tausta või kirjakeelset kõrgstiili (Pajusalu 2006); määratleja mingi sagedane kasutus rõhutab kogu vestluse argikeelsust (Pajusalu 2000) jne.

Siinses artiklis vaatleme mõningaid kontekste, milles eesti demonstratiive ja personaalpronoomeneid kasutatakse. Püüame näidata, milles seisneb iga vaadeldava konteksti omapära nii viitamise seisukohast üldisemalt kui deiktikute kasutuses konkreetsemalt. Iga olukorra osas analüüsime järgmisi kontekstuaalseid aspekte:

1) kuidas alustatakse suhtlustegevust, milliste kontekstualiseerivate vahenditega antakse märku algava suhtluse laadist;

2) kuidas luuakse referente, sealhulgas, kas ja kuidas mõjutavad viitamist konteksti ruumilised parameetrid ja kuidas mõjutab viitamist referendi infostaatus.

Vaatleme eelkõige kolme olukorda: spontaanseid argivestlusi, füüsilist konteksti katseolukorras ja pildiseeria põhjal (laste) jutustatud narratiive. Need olukorrad ei suuda loomulikult esindada kõigi võimalike kontekstide hulka. Pigem püüame 
esitleda mõningaid üksteisest väga erinevaid viitamisolukordi ja selle kaudu avada viitamise kontekstiliste omaduste paljusust. Samuti on eesmärgiks leida need omadused, mille poolest katselised olukorrad paratamatult erinevad loomulikest.

\section{Legod, argivestlused ja pildinarratiivid: olukor- dade üldkirjeldus}

Siinses artiklis käsitletud kontekste seob omavahel see, et neid on algupäraselt uuritud viitesuhete vaatenurgast (Pajusalu 2005, Kirsipuu 2009, Reile 2011, Kirsipuu jt 2012). Siinkohal seame oma eesmärgiks käsitleda neid olukordi sellest seisukohast, kuidas erinevad neis need keelelised vahendid, millega signaliseeritakse erinevaid konteksti omadusi.

\subsection{Argivestlused}

Argivestlus on eestikeelse suhtluse uurimises juba traditsiooniline keelekasutusolukord (vt nt Hennoste 2003), neid oleme enim uurinud ka referentsiaalsete suhete seisukohast. Renate Pajusalu (2005) on oma varasemates uurimustes vaadelnud pronoomenite kasutust eri tüüpi loomulikes argivestlustes. Helen Kirsipuu analüüsis oma bakalaureusetöös (2009) argivestluste 500 järjestikuse noomenifraasi referentsiaalseid omadusi. Uurimismaterjal on mõlemal pärit Tartu Ülikooli suulise eesti keele korpusest, Pajusalul erinevatest vestlustest, Kirsipuul kolmest vestlusest: perekondlik söömaaeg, mille ajal räägitakse reisimuljeid; kahe sõbranna vestlus teejoomise ajal ning kahe noore külaskäik vanema sugulase juurde. Peamine rõhk Kirsipuu analüüsis oli fraasitüüpidel ning määratlejate kasutusel ning põhiliseks eesmärgiks oli vaadelda, kas ja kuidas eristatakse mitteametlikes vestluses erineva infostaatusega referente.

Argivestluste temaatika on hüplev, vestlustes ei tõuse tüüpiliselt esile konkreetset läbivat teemat. Referendid tavaliselt ei eksisteeri kõnelejate vahetus ümbruses, kõnelejatel moodustub 
referentsiaalne võrgustik, milles referentide infostaatus muutub pidevalt: tuuakse juurde uusi ja kinnitatakse vanade referentide representatsioone. Mõnikord, kui samast referendist räägitakse kaua, moodustuvad pikad viiteahelad.

\subsection{Katse legoklotsidega}

Teisena vaatleme katset, milles vastupidiselt argivestlustele on oluline referentide paiknemine suhtluse füüsilises ruumis. Eesti keele demonstratiive pole siiani füüsilises situatsioonis kuigivõrd uuritud (v.a mõnevõrra lõunaeesti kolmeliikmelist süsteemi, vt Pajusalu 1999 ja 2002). Lünga täitmiseks koostas Maria Reile katse Kenny Coventry ning tema kolleegide (2008) ja Paul Piweki ning tema kaasautorite (2008) katsetele tuginedes (vt Reile 2011). Igast katsest võtsid osa kaks üliõpilast, kelle ülesandeks oli ehitada lauale asetatud legoklotsidest maja. Üks katsealustest oli juhendaja, teine ehitaja. Juhendaja andis maketi järgi juhiseid, millist klotsi võtta ja kuhu panna (ehitaja maketti näha ei võinud), ehitaja tohtis võtta korraga laualt ühe klotsi, kui oli selle kohta juhised saanud. Juhendaja klotse liigutada ei tohtinud, küll oli aga lubatud käega osutamine.

Katsealusteks valiti 18-30 aastased tudengid, kes olid pärit nii Põhja-, Kesk- kui Lõuna-Eestist ja Hiiumaalt. Kokku viidi läbi 10 katset. Klotsid asusid laual katsealuste ees jaotatuna enam-vähem võrdselt käeulatusse ja käeulatuse piirkonnast väljapoole ${ }^{2}$. Reile korraldatud katses tekkis konkreetne füüsilise ruumi situatsioon, kus juhendaja pidi ühelt poolt märkima referendi asukoha ja teisalt juhtima ehitaja tähelepanu kindlaks määratud objektidele. Seni on analüüsitud eelkõige neid kõneakte, mille abil juhendaja osutas ehitajale, millise klotsi see järgmisena peab võtma (vt Reile 2011).

Võrreldes argivestlustega on viiteahelad selles katses lühikesed, kord leitud klotsi ei lähe suhtlejatel hiljem enam

2 Vaata joonist lisa 1, $75 \mathrm{~cm}$ piirjoon märgib käeulatusse ja sellest väljapoole jäävate klotside jaotumist. 
vaja. Esmamainimise ülesanne on õige klotsi leidmine, selle kui referendi konstrueerimine sõltub rollist, mida juhendaja endale võtab: ta kas haarab kogu juhtimise enda kätte või arvestab ehitaja kui võrdväärse partneriga.

\subsection{Pildinarratiivid}

Kolmas vaadeldav kontekst on pildiseeria põhjal jutustatud narratiivid ${ }^{3}$, mille noomenifraasid on kodeeritud samadel põhimõtetel kui argivestluste omad. Kokku kasutati selles uurimuses 41 lapse (vanuses 6-7 aastat) ning 19 täiskasvanu (vanuses 20-30) narratiive. Nii lapsed kui täiskasvanud said ülesande jutustada piltide põhjal lugu poisist ja tüdrukust kelgumäel.

Katseliselt saadud narratiivide kontekst erineb oluliselt nii argivestlustest kui loomulikult ka legoklotsikatsest. Katsealused on asetatud kunstlikku olukorda, kus nad jutustavad lugu, mille tegelased on piltidel näha. Tegelasi on vähe, neile viidatakse korduvalt. Kõnelejad ei kaldu teemast kõrvale ega kommenteeri kuidagi sündmusi, sest nad ei ole pildiseerias juhtuvast otseselt huvitatud.

\section{Konteksti signaliseerimine suhtlustegevuse alguses}

Vaadeldavatest olukordadest on üks grupp loomulikke vestlusi ja kaks katselist olukorda. Loomulikes argivestlustes võib uue suhtlustegevuse alguse signaliseerimist näha eelkõige narratiivide ${ }^{4}$ alguses, kus võib esineda verbialgulisi lausungeid (vt ka nt Lindström 2000), milles esitletakse indefiniitse määratlejaga noomenifraasiga loo peategelane või peategelased. Näi-

3 Selles uurimuses osales ka Piret Soodla, täpsemalt vt Kirsipuu jt (2012). Kasutatud laste narratiivid pärinevadki Soodla väitekirjast (2011). Pildiseeria on esitatud lisas 2.

4 Eestikeelseid suulistest narratiividest suhtlustegevusena on ülevaate teinud Liina Lindström ja Piret Toomet (2000). 
tes (1) on see oli ja on praegu üks Jõmmi Tiit. Enne seda on kõneleja küll ka otse öelnud, et ta hakkab lugu jutustama, kuid sellegipoolest on esimene lause ikkagi kanooniline narratiivi alguslause oli üks $X$. Sellele järgneb vestlustegevuse edasine täpsustus, üks vestluskaaslastest küsib, ot kas see on anekdoot vä?, mille peale jutustaja liigitab oma tulevase narratiivi hoopis tõestisündinud looks.

(1) argivestlus TÜ suulise kõne korpusest

$\mathrm{MN}$ : jah. (0.5) no (1.2) räägin 'lühidalt (.) 'ära, (1.5) ee (2.2) $\mathrm{MN}$ : oli $(0.8)$

$\rightarrow \mathrm{MN}$ : ja on (0.8) praegu üks Jõmmi Tiit. (0.8) üks [ ee] ET: [ ((naerab)) ]

JV:@'inimene@

$\mathrm{MN}$ : inimene?=

$\mathrm{JV}:=@$.hjaah @ $=$

$\rightarrow \mathrm{ET}$ : $=$ 'ot kas se on 'anekdoot=vä $(0.8)$

$\mathrm{MN}$ : ei ole. (...)

JV: .hei=

$\rightarrow \mathrm{MN}:=$ 'tõestsündind 'lugu=

$\mathrm{JV}:=\mathrm{a}^{\prime} \operatorname{ssoo}$

MN: kes on (1.0) üks'silmaline? (0.8)

On selge, et katselises olukorras antakse suhtlussündmuse põhiolemuse kirjeldus eksperimentaatori poolt. Kuna tegemist on kunstliku olukorraga, on „välja lülitatud” paljud olulised konteksti loovad tegurid: tegevuslik kontekst legoklotside katses või narratiiv pildiseeria katses on ette antud, ei ole enam vajadust tegevuse algust signaliseerida.

Legoklotside katses on eksperimentaator see, kes annab märku, millal katsealused tegevust alustada võivad, pannes kaamera käima ning andes loa ka verbaalselt. Siiski, kuna katsest võtsid osa korraga kaks inimest, leidsid viie salvestuse juhendajad kümnest, et peaks partnerile tegevuse algusest mingil moel märku andma. Kolm neist kasutasid uue tegevuse algust signaliseerivat partiklit nii (näide 2, vt nii funktsioonide kohta Keevallik 2010), kaks aga üneemi aah ja ää (3). 
(2) J: nii võta see punane ja see kollane ja kollane pane vasakule poole (.) kõrvuti

(3) J: aaah võta see

Samuti algavad pildipõhised narratiivid tavaliselt markeerimata lausungitega, v.a mõni harv juhtum, kus juttu alustatakse ajamäärusega (ükskord).

(4) ükskord ilusal soojal päeval läksid lapsed kelgutama.

On huvitav, et taoline ajaadverbiaaliga markeeritud narratiivi algus esines kuue lapse jutustuses, seevastu ei esinenud seda mitte üheski täiskasvanu narratiivis. Kolmes täiskasvanu narratiivis esines siiski narratiivi alguslauses konkreetne ajaline määratlus, nagu vastlapäeval näites (5).

(5) Peep ja Mari läksid vastlapäeval välja kelgutama.

\section{Referentide loomine ja identifitseerimine}

\subsection{Referendi loomine argivestluses: mõned näited}

Referendid, millest vestluses kõneldakse, on kõnelejate ühiselt loodud mentaalsed representatsioonid. Eriti selgelt tuleb see välja referentide puhul, millele kõneleja raskustega nime otsib. Näites (6) kirjeldab kõneleja teatrimajas valitsevat meeleolu, viidates sellele kõigepealt pronoomeniga see ja seejärel mitmeid takerdumisi sisaldava fraasiga mingi eriline ee hh selline meeleolu ja veelkordse kõhklusega või mis see on. Ka pärast seda ei ole referent ilmselt veel ,valmis”, vaid seda alles hakatakse kirjeldama, kuid sellise viiteahelaga on avatud koht erilisele ja raskesti kirjeldatavale referendile.

(6) TÜ suulise kõne korpusest

endale õutsalt 'meeldib $(0,8)$ see on 'ültse kuidagi mingi 
'eriline ee hh selline 'meeleolu või mis see $=$ on kui sa tuled 'teatrisse 'pühapäeva 'hommikul, $(0,5)$ noh tuled mingi kella poole üheteistkümneks teatrisse, laulad laulud 'läbi ja=sis. $(0,8)$

Kuigi eesti keele demonstratiivide valik pole väga suur ainult see, harva ka too ja lokatiivsete demonstratiivide vormid (siin, seal jne), võivad needki mõnikord vastanduda ja luua eri tüüpi referente. Üldiselt viitavad demonstratiivproadverbid pigem kohale ja demonstratiivpronoomen see pigem asjale. Kirjakeele korpuses leidunud näites (7) kasutatakse nii demonstratiivpronoomenit see kui demonstratiivproadverbe siit ja seal. Nende abil tekib kujutlus ruumist, mis jaguneb siin ehk maa peal olevaks osaks ja seal taga, hiljem ka seal olevaks osaks. Neid osi eristab see suur must palakas, millele viidatakse erinevalt ruumireferentidest demonstratiivpronoomeniga see (selle sisse) ja mis seetõttu võrreldes ruumi osadega püsib pigem esemelisena.

(7) TÜ kirjakeele korpusest

Midagi jääb selle suure musta palaka taha. Kui keegi selle sisse suurema augu jaksaks teha, siis me võiksime siit maa pealt näha, mis seal taga kõik on. Seal on valge, see on kindel.

Sarnane referentide loomine adverbi ja demonstratiivpronoomeni abil toimub tunduvalt vähem filosoofilises kontekstis näites (8): seal loob kogu olukorda ehk tulevast pidu loova sündmuse referendi, see aga viitab juba varem nimetatud hinnale palju konkreetsemalt.

(8) TÜ suulise kõne korpusest

$\mathrm{ma}=\mathrm{e} i=$ tea? üle neljakümne krooni. ei=tea mis seal 'maksab, 'jooke selle sees ei ole, ütleme mingisugune 'üür.

Argivestluste põhjalikumal analüüsil selgus, et referendi esmamainimisel kasutati puhast substantiivi 105 ning substan- 
tiivist ja adjektiivist koosnevat NP-d 10 korda, määratlejaga fraase aga 136 korda. Üldiselt viidatakse uuritavates argivestlustes laiendamata substantiiviga vaid referente, mis maailmas või käimasoleva vestluse kontekstis on ühemõttelised ja lihtsalt identifitseeritavad (ja emme rääkis et; aga korjas passid ära ka või). Esmamainimisel püütakse enamasti võimalikult palju infot ühte NP-sse ,pakkida”, näiteks lisatakse määratleja (9), kasutatakse koos nii määratlejat kui adjektiivi (10) vms.

(9) selles (1.0) toidupoes on 'need, (0.6) saiakesed

(10) $a=$ sul 'oligi seal väikses seltskonnas nagu 'mõnusam olla

Määratlejate (see, üks, mõni, kõik jms) kasutus NP koosseisus on eesti keele suulises kõnes suhteliselt sagedane (vt ka Pajusalu 1999, 2000). Meie materjalist ilmneb, et enamasti kasutatakse argivestlustes määratlejaid selleks, et tuua diskursusesse sisse uus referent. Kui pronoomenite igasugune, kuskil, mingisugune, mõni, üks jt kasutus uuele referendile viitamiseks on igati ootuspärane, siis huvitaval kombel kasutatakse määratlejat see samuti valdavalt koos uuele referendile viitava NP-ga. Greenbergi (2005) järgi on keeltes tavaline grammatiseerumisprotsess, mille käigus demonstratiivpronoomenist saab artikkel; artikliks võibki pidada sellist demonstratiivi, mida kasutatakse varem mainimata referendile viitamiseks, st siis, kui referent on tuvastatav ühiste teadmiste vms kaudu (vt ka Laury 1997, Pajusalu 1999, vastuväiteid eesti see tõlgendamisele artiklina vt aga Sahkai 2003). Meie poolt uuritud argivestlustes on määratlejat see kasutatud 28 korrast vaid 8-1 juba mainitud referendile viitava NP koosseisus. 20 korral esineb demonstratiivpronoomen koos NP-ga, mis viitab seni mainimata referendile, kuid mis on tuvastatav muul viisil. Siinse artikli materjalile tuginedes võib öelda, et argivestlustes kasutatakse määratlejat see enamasti selleks, et kuulaja saaks oma teadmiste põhjal paigaldada uue referendi representatsioonide võrgustikku. Kas referent ise on tekstis varem esinenud või mitte, ei ole määratleja valikul ainuke oluline kriteerium, oluline on see, et referent oleks konteksti kaudu tuvastatav (sh nt vestlejate eelteadmised olukorrast; 
kõnelemine varem toimunud sündmusest, milles kõik vestlejad on osalenud; mingi kõigile kõnelejatele teada oleva uudise teemal arutlemine jne).

Näites (11) on näha see kasutus entiteedi esmakordsel mainimisel.

(11) vaatas ainult=õ (.) seda autore- (1.2) seda seda (1.0) auto'numbrit. (1.4) regist'reerimise'numbrit

Vestluses, millest pärineb näide (12), räägitakse sellest, kuidas ülikooli kõrvalt tööl käimine õpinguid segab. Et on üldteada fakt, et ülikoolis kuulatakse loenguid, siis on see kasutus mõistetav ka loengute varasema mainimiseta.

(12) aga kuda sa saad, a sa saad 'teiste käest sis need `loengud võ kudas

Määratleja $\ddot{u} k s$ kasutus on vestlustes ühtsem, seda kasutatakse vaid uuele, kuulaja jaoks veel tundmatule referendile viitamiseks (13, vt ka Pajusalu 2000).

(13) ja üks 'seltskond oli 'ratastega.

Seega, määratleja kasutus ei sõltu argivestlustes sellest, kas referent on mainitud või mainimata, vaid hoopis sellest, kas kuulaja eeldab, et kõneleja peaks referenti teadma või mitte. Niisiis kasutatakse demonstratiivi see juhul, kui arvatakse, et kuulaja suudab referendi piisavalt identifitseerida, pronoomen üks leiab kasutust aga siis, kui kõneleja eeldab, et kuulaja ei tea referenti.

Kahes järgnevalt käsitletavas katselises olukorras on viidatavad referendid kõnelejale ette antud: need on vastavalt legoklotsid laual või isikud ja esemed piltidel. Olukord on seega argivestlusest väga erinev. 


\subsection{Legoklotside identifitseerimine}

Legoklotside katses on referente vaja identifitseerida, nende sisemine olemus ei mängi rolli, sest nad on käimasoleva tegevuse suhtes kõik põhimõtteliselt võrdsed, erinedes vaid selle poolest, kas parajasti viidatav on ehitusjärjekorra suhtes õige või mitte. Küll aga on need klotsid erineval kaugusel juhendajast ja ehitajast. Kuna tegemist on paariskatsega, hakkab referendi olemuse asemel antud katses mängima rolli juhendaja suhestumine ehitajaga - kas juhendaja on asetanud end käskija rolli või võtab ta katses ehitajat võrdse partnerina, soovides koos lahendada ülesannet, õigete klotside leidmist ja maja ehitamist. Lähtudes sellest, juhendaja kas kõigepealt kirjeldas referenti, luues sellega ehitaja silme ette viidatava referendi kujutluspildi, ning seejärel viitas referendile demonstratiiviga, või jättis kirjelduse vahele ning viitas demonstratiiviga kohe, lisades kirjelduse hiljem täpsustuseks.

Näites (14) kaasab juhendaja ehitajat referendi otsimisse, andes talle eelnevalt selle kirjelduse, näites (15) aga viitab demonstratiiviga, täpsustades hiljem referenti.

(14) J: jamh sis ö võtaa väiksem kollane aga mitte kõge=väiksem kollane nagu sama suur nagu=se punane ja võta eee see nurgast sealt

(15) J: ee nüüd läheb see sinine

Demonstratiivide valikut viitamiseks füüsilises situatsioonis on traditsiooniliselt selgitatud eelkõige kaugusopositsiooniga: ühe või teise demonstratiivi valik sõltub viidatava referendi kaugusest kas kõnelejast või adressaadist või neist mõlemast (vt nt Lyons 1977, Fillmore 1997). Sellest on enamasti lähtutud ka eesti keele demonstratiivide selgitamisel. EKG I (1995: 29) järgi viitab kirjakeeles see ajas või ruumis lähedasemale, too kaugemale referendile.

Kõigepealt võib öelda, et suurema osa viitamiste puhul kasutas juhendav katseisik ka osutavat žesti. Kui osutavat žesti ei kasutatud, oli referent kas mingil viisil kergesti eristatav (näiteks laual viimane omataoline) või sooritas žesti hoopis ehitaja. 
Kõige suurema rühma moodustasid demonstratiivi see sisaldavad NP-d (16) või see üksinda (17). Erinevalt oodatust ei esinenud mitte kordagi demonstratiiv too, ka mitte nende juhendajate puhul, kes olid pärit Lõuna-Eestist või märkisid katsejärgses ankeedis end seda kasutavat.

(16) $\mathrm{J}$ : ja=sis nende kahe peale lähäb see punane

(17) J: siss se

Järgmise suurema rühma moodustasid NP-d, milles puudus määratleja ja mis koosnesid ainult klotsi kirjeldusest koos žestiga või ilma (18).

(18) J: nüd lähäb kõge väiksem punane klots mida on ainult üks alles

Ülejäänud viitamistel kasutati nii kirjeldusi kui lisati asukoha määratlemiseks demonstratiivseid proadverbe siin, siit, seal ja sealt.

Lähedal asuvatele (lähemal kui $75 \mathrm{~cm}$ ehk käeulatuses ${ }^{5}$ ) klotsidele viitamisel kasutati ainult demonstratiivi see sama tihti kui seeNP-d (28\%). Kaugel asuvatele referentidele viidati demonstratiiviga see ainult $14 \%$ juhtudest, kusjuures alati koos osutava žestiga, ja seeNP-ga $26 \%$ juhtudest. Sellest saab järeldada, et kui referendid asusid kaugel, eelistasid juhendajad kasutada pikemat fraasi (seeNP-d).

Märgatavat erinevust on näha ka proadverbide siin, siit ja seal, sealt kasutuses. Kaugel asuvate klotside puhul kasutati 14\%-1 juhtudest lisaks demonstratiivile see veel klotsi ja/või asukoha kirjeldust ning proadverbe seal, sealt, mõnikord pikema fraasi sees (19).

(19) J: sis=see keskmine kollane mis=on seal kõige kaugemal

5 Kaugus $75 \mathrm{~cm}$ on osutunud oluliseks varasemates uurimustes (Coventry jt 2008), siinkohal ei ole vaadeldud, kas see ka eesti keele puhul paika peab. 
Lähedal asuvate klotside korral kasutati vastavaid proadverbe siin ja siit (20) ainult 7\%-1 juhtudest, mis on pea poole vähem kui kaugel asuvate klotside puhul. Ka sellest võib järeldada, et kaugel asuvate entiteetide puhul peavad juhendajad vajalikuks anda ehitajale referendi asukoha kohta rohkem informatsiooni.

(20) J: siis siia külje peale lähäb suur kollane (.) see kollane siin

Katsest ilmnesid mõned erijuhud, kus proadverbe siin, siit ja seal, sealt kasutati nende tähendusele „vastupidiselt”: lähedal asuvatele referentidele viidati mõnikord demonstratiividega seal, sealt ja kaugel asuvatele demonstratiividega siin, siit. Selliseid kasutusi ei saa enam selgitada kaugusopositsiooniga, vaid referendi ligipääsetavusega. Ligipääsetavuse all mõeldakse mõnikord referendi olemist tähelepanu fookuses või sellest väljaspool (Piwek jt 2008), mõnikord aga seda, kuivõrd selgelt on referent nähtav (Jarbou 2010). Demonstratiivi seal kasutati ainult nähtavuspõhisele ligipääsetavusele tuginedes - adressaadile anti selle abil märku, et viidatud referent ei ole kergesti eristatav ega väga nähtaval, ning referendi leidmiseks tuleb rohkem pingutada (21).

$\mathrm{J}$ : sis võta üks ota $\mathrm{se}=\mathrm{ei}$ ole tegelikult praegu (.) pane see korra kõrvale

E: ((paneb klotsi kõrvale))

$\mathrm{J}$ : ja võtaa see punane seal

Viidatav klots asus kätte näitamise hetkel teiste pikkade klotside taga ning polnud seetõttu visuaalselt hästi eristuv (vt lisa 1 , klots 5pp).

Kuigi katsetes ilmnesid mõned demonstratiivide kasutused, mida ei saa kaugusopositsiooniga selgitada, võib siiski öelda, et kirjeldatud füüsilises situatsioonis lähtutakse klotsidele viitavate demonstratiivide valikut tehes eelkõige nende asupaigast. Siiski näitavad mõned esinenud kõrvalekaldumised (21), et 
demonstratiivi valikuga võidakse kuulaja „ümber lülitada” ühelt tõlgendamisprintsiibilt teisele: ruumilistelt parameetritelt ligipääsetavusele.

Kuigi eesti keele ühiskeeles on kaks ruumiliselt vastanduvat demonstratiivpronoomenit (see ja too), kasutasid katsealused ainult demonstratiivi see. Täpsustava asukoha määrajana lisati proadverbe siin, siit, seal või sealt. Niisiis võib sarnaselt juba varem leitule (Larjavaara 1990: 36 eesti keele kohta, vt ka Diessel 1999 demonstratiividest üldisemalt) öelda, et see on sellises olukorras distantsneutraalne demonstratiiv, kandes endas eelkõige tähelepanu juhtija rolli. Referendi asukohta antakse aga edasi proadverbide siin, siit, seal ja sealt abil ja/või lisatakse asukoha kirjeldus.

\subsection{Referentide identifitseerimine ja loomine pildinarratiivides}

Pildinarratiivides on referendid nagu legokatseski katseolukorra poolt ette antud. Siiski pole need mitte staatilised klotsid, millest igaüht on tarvis viidata vaid ühe korra, vaid sündmuse tegelased, kelle rollid sündmuses muutuvad ja kellel on jutustuse eri hetkedel erinev infostaatus. Katseolukorda iseloomustab, et viidatavaid tegelasi on vähe, neile viidatakse korduvalt, kõneleja ei kaldu teemast kõrvale ega kommenteeri kuidagi sündmusi.

Sagedasemate fraasidena esinesid laste (6-7 a) narratiivides laiendamata substantiivid ja pronoomenid. Määratlejaga fraase on see-eest kasutatud vaid 5\% juhtudel. Laste narratiivides on enim kasutatud määratlejateks see ja $\ddot{u} k s$, mis olid sagedasemad määratlejad ka täiskasvanute vestlustes. Siiski jääb nende määratlejate kasutus kogu NP-de hulka arvestades marginaalseks ning ka muid määratlejaid esineb väga vähe.

Ehkki jutustuste iseloomu arvestades võiks eeldada, et tegelased juhatatakse sisse fraasidega $\ddot{k} k s$ poiss/tüdruk/laps või mingi poiss/tüdruk/laps, leidus sellist määratleja kasutust 41-st jutust vaid viie narratiivi alguses (nagu nt 22). 
(22) et üks tüdruk hakkas liugu laskma.

Peamiselt alustati juttu määratlejata NP-ga ning sellisel juhul kasutati üldiselt kogu narratiivi vältel määratlejata substantiivi või asendati see pronoomeniga (23).

(23) tüdruk lasi kelguga alla. siis sõitis vastu puud. poiss $e i$ tüdruk hakkas nutma.

Pisut harvemini anti narratiivi esimeses lausungis tegelastele nimi ning jutustamise käigus viidati referentidele sel juhul kas pärisnime või pronoomeniga (24).

(24) elasid kord Mari ja Oskar. nad läksid mäele kelgutama. lumine ilm oli. Mari kukkus kelgu pealt maha.

6-7 aastaste laste narratiivides esines määratlejaid vähe ning nende kasutus ei sõltunud alati sellest, kas referent oli jutus uus või tuntud. Pronoomenit $\ddot{u} k s$ kasutati küll alati koos uue referendiga, ent see esines samuti pigem uue referendiga (25, narratiivi esimene lausung).

(25) läks niimoodi et see tüdruk sõidaks alla ja sõidaks kogemata vastu puud.

Selgub, et laste narratiivides ei ole referendi infostaatuse märkimine kuigi olulisel kohal. Meie andmestikus pole selgeid märke sellest, et lapsed eristaksid lugusid jutustades uusi referente vanadest referentidest. Ilmselt on selle põhjustajaks asjaolu, et jutustatakse pildiseeria alusel - pildid on näha nii jutustajale kui ka kuulajale ning seega võib laps automaatselt eeldada, et kuulaja teab kõiki referente, kuna näeb neid piltidelt.

Kontrollgrupina kasutasime ka 19 täiskasvanu jutustatud narratiivi. Kokkuvõtlikult võib öelda, et võrreldes laste narratiividega olid täiskasvanute omad ligi poole võrra pikemad. Ka erinevaid fraasitüüpe esines täiskasvanute juttudes rohkem, ent sagedasemad fraasitüübid olid sarnaselt laste narratiividele laien- 
damata substantiiv ja pronoomen, samuti esines sageli pärisnimesid.

Võrreldes lastega kasutavad täiskasvanud määratlejaid rohkem juba varem mainitud referendile viitamiseks. Kui laste juttudes kasutati määratlejaid peamiselt just esimeste mainimiste korral, siis täiskasvanud lisavad määratleja pigem NP-le, mille referent on juba teada või mis on saadaval.

\section{Kokkuvõte}

Artiklis käsitlesime kolme erinevat viitamiskonteksti argivestlust, legoklotside katset, ja pildiseeria põhjal loodud narratiivi - ja kahte tüüpi kõnelejaid - noori täiskasvanuid ja lapsi. Hoolimata omavahelisest erinevusest ei suuda need kontekstinäited katta kõiki võimalikke olukordi ja kõnelejate tüüpe, kuid esitavad loodetavasti sellise komplekti, millest on näha viitamisvõimaluste erinevuste määr ja mõned teed nende uurimiseks.

Analüüsisime keelelisi vahendeid, mille abil suhtlejad signaliseerivad vestlustegevuse iseloomu. Kõige selgemini ilmnevad need argivestluste narratiivide alguses, katselise olukorra narratiive ei pea aga kõnelejad oluliseks narratiividena markeerida. Füüsilise tegevuse juures andsid juhendajad ehitajatele juhiste andmise alustamise kohta märku kas sissejuhatava partikliga nii või üneemidega $a a h$, ääh, teise variandina pidasid nad piisavaks eksperimentaatori alustamist lubavat märguannet ning alustasid kohe referentidele viitamisega.

Selgitasime ka referentide loomise seaduspärasusi eri kontekstides. Füüsilises katseolukorras, kus on korraga palju sarnaseid referente, on demonstratiivil see eelkõige tähelepanu juhtija roll. Referendi asukohta antakse edasi proadverbidega siin, siit, seal ja sealt ja/või lisatakse asukoha kirjeldus. Argivestluste puhul ilmnes, et see toimib tuntuse määratlejana, muuhulgas ka juhtudel, kui see tuuakse vestlusesse esimest korda ja tuntus tuleneb kuulaja tehtud järeldusest. Määratleja üks laiendab NP-d siis, kui arvatakse, et kuulaja referenti ei tea. Vastupidiselt eelmainitud kontekstidele, kasutati pildi- 
põhistes narratiivides määratlejaid vähe. Seda võiks selgitada sellega, et vaadeldud narratiivide puhul ei olnud oluline mitte infostaatuse määramine (tegu oli niikuinii piiratud hulga referentidega), vaid pigem piltidel toimuv tegevus.

\section{Aadressid:}

Helen Hint, Maria Reile, Renate Pajusalu

Eesti ja üldkeeleteaduse instituut

Tartu Ülikool

Jakobi 2, 51014 Tartu

E-mail: Helen.Hint@ut.ee, Maria.Reile@ut.ee, Renate.Pajusalu@ut.ee

\section{Kirjandus}

Abbott, Barbara (2010) Reference. Oxford: Oxford University Press.

Ariel, Mira (2001) "Accessibility theory: and overview". In T. Sanders, J. Schilperoord, W. Spooren, eds. Text representation: linguistic and psycholinguistic aspects, 29-87. Amsterdam: John Benjamins.

Chafe, Wallace (1994) Discourse, consciousness, and time: the flow and displacement of conscious experience in speaking and writing. Chicago: The University of Chicago Press.

Coventry, Kenny R., Bernice Valdés, Alejandro Castillo, Pedro GuijarroFuentes (2008) "Language within your reach: near-far perceptual space and spatial demonstratives". Cognition 108, 3, 889-895.

Diessel, Holger (1999) Demonstratives: form, function and grammaticalization. Amsterdam and Philadelphia: John Benjamins.

Duranti, Alessandro, Charles Goodwin (1992) "Rethinking context: an introduction". In A. Duranti, C. Goodwin, eds. Rethinking context: language as an interactive phenomenon, 1-42. Cambridge: Cambridge University Press.

EKG I = Erelt, Mati, Reet Kasik, Helle Metslang, Henno Rajandi, Kristiina Ross, Henn Saari, Kaja Tael, Silvi Vare (1995) Eesti keele grammatika I. Eesti Teaduste Akadeemia Eesti Keele Instituut.

Etelämäki, Marja (2009) "The Finnish demonstrative pronouns in light of interaction". Journal of Pragmatics 41, 1, 25-46.

Fillmore, Charles J. (1997) Lectures on deixis. Stanford: CSLI Publications.

Greenberg, Joseph (2005) Genetic linguistics: essays on theory and method. William Croft, ed. Oxford: Oxford University Press.

Gumperz, John J. (1982) Discourse strategies. (Studies in Interactional Sociolinguistics, 1.) Cambridge: Cambridge University Press. 
Gundel, Jeanette, Nancy Hedberg, Ron Zacharski (1993) "Cognitive status and the form of referring expressions in discourse". Language 69, 274-307.

Gundel, Jeanette, Mamadou Bassene, Bryan Gordon, Linda Humnick, Amel Khalfaoui (2010) "Testing predictions of the givenness hierarchy framework: a crosslinguistic investigation". Journal of Pragmatics 42, 1770-1785.

Hanks, William F. (1996) Language and communicative practices. Chicago: Westview Press.

Hennoste, Tiit (2003) „Suulise eesti keele uurimine: korpus”. Keel ja Kirjandus 46, 7, 481-500.

Jarbou, Samir Omar (2010) "Accessibility vs. physical proximity: an analysis of exophoric demonstrative practice in Spoken Jordanian Arabic". Journal of Pragmatics 42, 11, 3078-3097.

Keevallik, Leelo (2010) "Marking boundaries between activities: the particle nii in Estonian". Research on Language and Social Interction 43, 2, $157-182$

Kirsipuu, Helen (2009) Noomenifraaside referentsiaalsed omadused argivestlustes. Bakalaureusetöö. Käsikiri Tartu Ülikooli eesti ja üldkeeleteaduse instituudis.

Kirsipuu, Helen, Piret Soodla, Renate Pajusalu (2012) "Referentsiaalsed noomenifraasid laste narratiivides". Eesti Rakenduslngvistika Ühingu Aastaraamat 8, 91-107.

Lambrecht, Knud (1994) Information structure and sentence form. topic, focus and the mental representation of discourse referents. Cambridge: Cambridge University Press.

Larjavaara, Matti (1990) Suomen deiksis. Helsinki: Suomalaisen Kirjallisuuden Seura.

Laury, Ritva (1997) Demonstratives in interaction: the emergence of a definite article in Finnish. Amsterdam and Philadelphia: John Benjamins.

Laury, Ritva (1999) “Definiteness". In Jef Verschueren, Jan-Ola Östman, Jan Blommaert, Cris Bulcaen, eds. Handbook of pragmatics. Amsterdam and Philadelphia: John Benjamins.

Lindström, Liina (2000) „Narratiiv ja selle sõnajärg”. Keel ja Kirjandus, 3, 190-200.

Lindström, Liina, Piret Toomet (2000) „Eesti suuliste narratiivide keelelisi erijooni”. Tiit Hennoste, toim. Eesti keele allkeeled, 174-203. Tartu: Tartu Ülikooli Kirjastus.

Lyons, Christopher (1999) Definiteness. Cambridge: Cambridge University Press.

Lyons, John (1977) Semantics 2. Cambridge: Cambridge University Press.

Pajusalu, Renate (1999) Deiktikud eesti keeles. (Disserationes philologiae Universitatis Tartuensis, 8.) Tartu: Tartu Ülikooli Kirjastus.

Pajusalu, Renate (2000) "Indefinite Determiners mingi and $\ddot{u} k s$ in Estonian". In Mati Erelt, ed. Estonian: typological studies IV, 87-117. Tartu: Tartu Ülikooli Kirjastus. 
Pajusalu, Renate (2002) "Referentsiaalne praktika kõneetnograafia uurimisvaldkonnana". Pajusalu, Renate, Ilona Tragel, Tiit Hennoste, Haldur Õim, toim. Teoreetiline keeleteadus Eestis, 209-221. Tartu: Tartu Ülikooli Kirjastus.

Pajusalu, Renate (2005) "Anaphoric pronouns in spoken Estonian: crossing the paradigms". In Ritva Laury, ed. Minimal reference: the use of pronouns in Finnish and Estonian discourse, 107-134. Helsinki: Suomalaisen Kirjallisuuden Seura.

Pajusalu, Renate (2006) "Death of a demonstrative: person and time: the case of Estonian too". Linguistica Uralica 42, 4, 241-253.

Piwek, Paul, Robbert-Jan Beun, Anita Cremers (2008) "'Proximal' and 'distal' in language and cognition: evidence from deictic demonstratives in Dutch". Journal of Pragmatics 40, 4, 694-718.

Reile, Maria (2011) Demonstratiivide kasutus ruumis. Magistritöö. Käsikiri Tartu Ülikooli eesti ja üldkeeleteaduse instituudis.

Sahkai, Heete (2003) "Demonstrative doubling in spoken Estonian". Trames $7,2,120-144$.

Silverstein, Michael (1976) "Shifters, linguistic categories and cultural description". In Keith H. Basso and Henry A. Selby, eds. Meaning in anthropology. Albuquerque: University of New Mexico Press.

Soodla, Piret (2011) Picture-elicited narratives of Estonian children at the kindergarten-school transition as a measure of language competence. (Dissertationas Pedagogicae Universitatis Tartuensis.) Tartu: Tartu University Press. 
182 Helen Hint, Maria Reile, Renate Pajusalu

Lisa 1. Objektide paigutus katse alguses

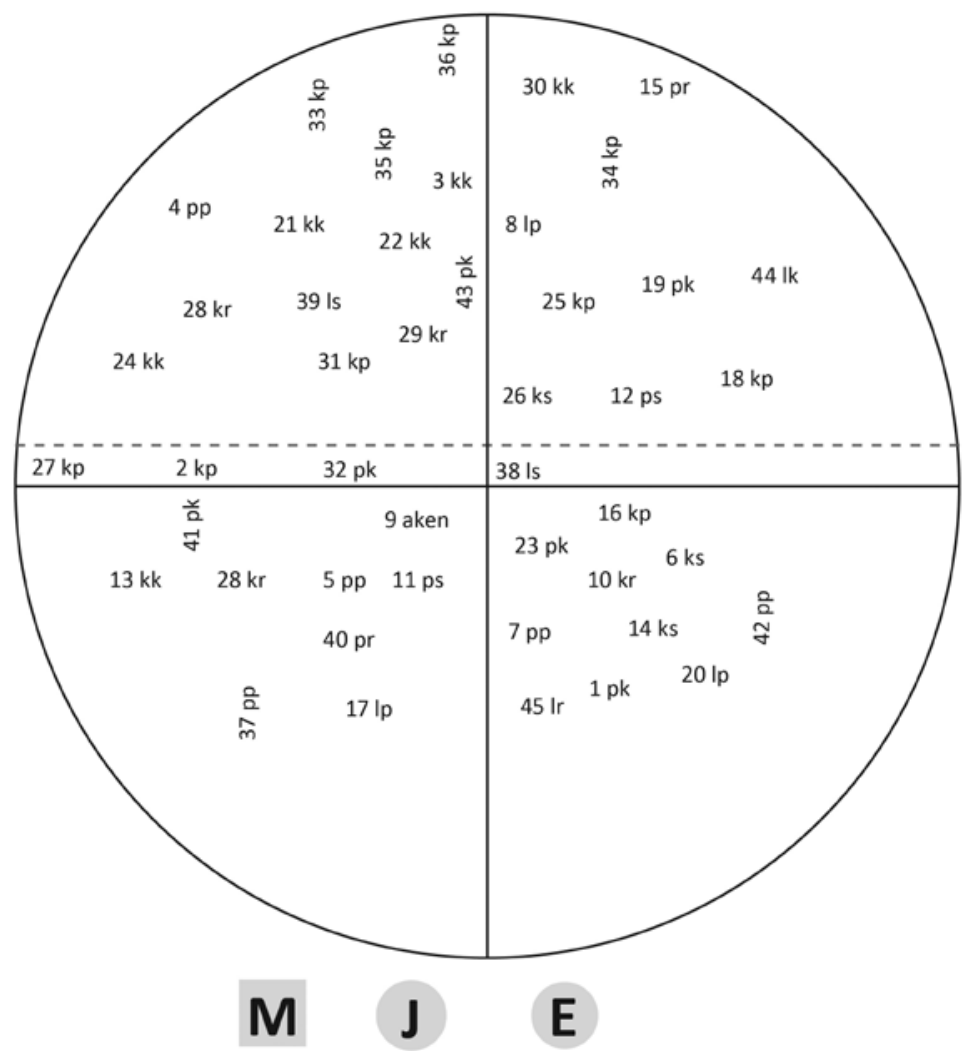

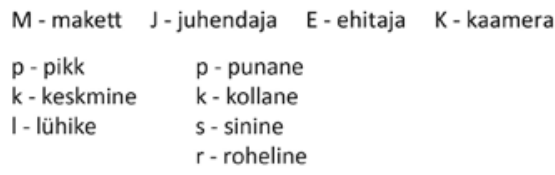

(Esimene täht tähistab klotsi suurust ja teine värvi)

- . - - $75 \mathrm{~cm}$ piir 
Lisa 2. Narratiivide jutustamise aluseks olnud pildiseeria
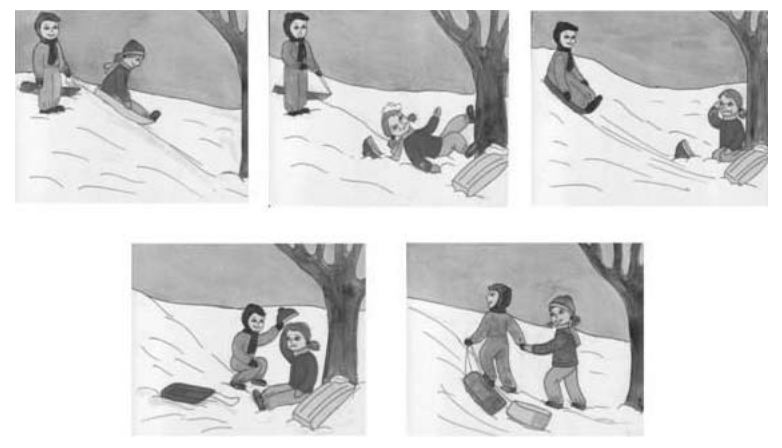

\begin{abstract}
Helen Hint, Maria Reile, and Renate Pajusalu: Context and reference: everyday conversations, Lego blocks and narratives. The article discusses context and context-creating means of reference. It is mainly based on three separate studies, all of which originally concentrated on referential devices. We examine contextualizing techniques in spontaneous everyday conversations and in two experimental situations: in an experiment with Lego blocks where one of the subjects builds a house using Lego blocks while being instructed by the other subject, and in narratives based on a picture sequence. The article compares the similarities and differences between these three contexts, concentrating particularly on the beginning of the conversational activity: signalling the nature of the activity and creating referents. Since some of the narratives are told by children the article also touches briefly the reference strategies of different age groups.
\end{abstract}

Keywords: context, reference, defniteness, demonstratives, pronouns, narrative, everyday conversation, child language, Estonian 